\title{
Knowledge and utilization of information communication technology (ICT) among health science students at the University of Gondar, North Western Ethiopia
}

\author{
Solomon Assefa Woreta ${ }^{1 *}$, Yigzaw Kebede ${ }^{2}$ and Desalegn Tegabu Zegeye ${ }^{2}$
}

\begin{abstract}
Background: Despite the relatively huge ICT investment and policy deployment in higher institutions in Ethiopia, there is still scant information about the success of implementation of the Information Communication Technology (ICT) in the higher education. This study, therefore, was carried out with an aim to assess knowledge and utilization of Information Communication Technology (ICT) among medicine and health science students and its associated factors in Gondar College of Medicine and Health sciences, University of Gondar.

Methods: A cross-sectional study was conducted at the College of Medicine and Health Sciences, University of Gondar, Ethiopia. Data regarding socio-demographic characteristics of the students, level of knowledge and utilization of ICT were collected by means of a self-administered questionnaire. Data was analyzed using SPSS version 13.

Results: A total of 1096 students responded giving a response rate of $97.8 \%$. The mean age of the study participants was $20.3( \pm 1.3)$ years. Females constitute only $26 \%$ of the respondents. The majority (79\%) were fulltime students. Only half of the respondents (51\%) had ICT knowledge and only $46 \%$ students utilized ICT while $47 \%$ of the respondents never used electronic communication (e.g. email or chat room) and 39\% of the respondents never used Microsoft office (e.g. word ${ }^{\circledR}$ or WordPerfect ${ }^{\circledR}$ ). ICT knowledge [AOR $=2.5,95 \%$ Cl: 1.7-3.5], family educational background $[\mathrm{AOR}=4.36,95 \% \mathrm{Cl}: 2.16-8.80]$, and perceived quality of training $[\mathrm{AOR}=1.9,95 \%$ Cl: 1.3-2.8] showed strong and positive associations with ICT utilization. Students from urban areas were more likely to utilize ICT compared with those from rural areas [AOR $=2.7,95 \% \mathrm{Cl}: 2.097,3.497$ ], and information technology training was found to be positively associated with ICT utilization [AOR $=2.07,95 \% \mathrm{Cl}: 1.18,3.62]$.
\end{abstract}

Conclusions: The result showed that students' knowledge was inadequate and utilization of ICT was poor. Therefore, the university should sustain professional development to improve teaching, to raise student performance and equip the college with student centered ICT computer labs to increase students' ICT utilization.

\section{Background}

The use of ICT to enhance or support learning and teaching in education has become increasingly important in tertiary education [1]. Hence, ICT skills are currently of great interest to governments, businesses and individuals. Information Communication Technology (ICT) has become a powerful tool in the fight against world poverty, providing

\footnotetext{
* Correspondence: solomonazezo@gmail.com

${ }^{1}$ Institute of Public Health, Department of Health Informatics, University of Gondar, Gondar, Ethiopia

Full list of author information is available at the end of the article
}

developing countries with an unprecedented opportunity to meet vital development goals, such as poverty reduction, basic health care, and education, far more effectively than before [2]. Information communication technology in education is a modern, efficient and cost-effective process and has created a need to transform how students from higher institutions learn [3].

Compared with developed countries, the use of ICT in education programs in developing nations is relatively limited. Some of the reasons mentioned for such gaps are because developing countries face shortages of

\section{Biomed Central}


financial resources, limited Internet access, a lack of trained teachers and the lack of proper policies. Nevertheless, there has been growing interest in the use of ICT in educational settings in developing countries. Furthermore, in recent years, several countries have attempted government led initiatives to expand access to ICT in schools. These initiatives have often been associated with a broader educational quality improvement agenda [4].

Like any other developing country, the Ethiopian government has an e-government strategy which covers various sectors such as education, health, agriculture, and public administration [5].

The University of Gondar, as one of the prominent tertiary institutions in Ethiopia, recognizes the broad positive effect of ICT on the quality of learning and is involved in the implementation of various interventions.

The aim of this study is therefore, to assess knowledge and utilization of Information Communication Technology (ICT) among Medicine and Health Science students and its associated factors in College of Medicine and Health Sciences, University of Gondar.

\section{Methods}

The study was carried out at the College of Medicine and Health Sciences, University of Gondar. Currently, the College of Medicine and Health Sciences comprises 4 schools, namely, School of Medicine, School of Public Health, School of Health Sciences and School of Pharmacy. Under these four schools there are 35 departments running 11 undergraduate and 8 postgraduate study programs. In 2011, there were more than 4200 students enrolled in the undergraduate regular, continuing and postgraduate programs in the college. The Department of Health informatics was established in 2005 and since then it has been running the Introduction to Health Informatics course to all undergraduate health Science students. The contents of the course are basic computing, Health information systems and health informatics applications. The department owns 2 computer labs, each with 50 computers and broadband Internet access.

During the study period, the College of Medicine and Health Sciences was teaching more than 4205 graduate and undergraduate students.

Cluster sampling was used to ensure all classes and sexes were included proportionally into the study. Proportional sample numbers of students were taken from all departments and sections. Then the study subjects were selected by systematic random sampling from each department according to alphabetical name lists. Finally, 1119 participants from 3306 fulltime and part time undergraduate students were enrolled in the study.

A structured questionnaire was designed by reviewing the literature. It was pretested on a group of 56 students who did not belong to the selected clusters. The structured questionnaire assessed basic IT skills and knowledge of computer hardware, computer software, computer input devices, computer output devices, basic computer terms and definitions and general understanding of how a computer works. In total 16 questions on ICT knowledge were asked to indicate the level of ICT knowledge, with each statement using a four-point Likert scale. The average score for each question was used to assess knowledge. The average for all 16 ICT knowledge questions was calculated and those with above average score were labeled as knowledgeable while those below were labeled as non-knowledgeable. In this study 11 ICT Utilization questions were also asked to indicate their level of ICT utilization with each statement on a five-point Likert scale. ICT utilization was assessed by using the average score for each of these questions. An average for the 11 ICT utilization questions was calculated and those with above the average score were labeled as utilized and those below were labeled as non-utilized. The study was approved by the Institutional Review Board of the University of Gondar. Oral informed consent was obtained from each participant.

Data analysis was carried out using SPSS (Statistical Package for Social Sciences) version 13. Descriptive analyses were performed for various variables. Bivariate and multivariate logistic regression analysis was conducted. Variables found to have an association $(\mathrm{p}<0.2)$ with the dependent variables, were identified and entered to control the possible confounding effects.

\section{Results}

\section{Socio-demographic characteristics of students}

A total of 1096 students from 11 departments were randomly selected and included in the study, with a response rate of $97.8 \%$. The age range of participants was from 19 to 31 years with a mean (SD) of $20.34( \pm 1.38)$ years. Three quarters of the respondents (74\%) were male, $61 \%$ were from urban regions and $79 \%$ were fulltime students. Three hundred and fifty eight students (33\%) were first year students, 365 (33\%) in second year and 373 (34\%) were in the third year or above.

Socio-demographic characteristics of students are described in Table 1.

\section{Student knowledge on ICT}

It was observed from the study that $51 \%$ of the respondents had knowledge of ICT, of which $29 \%$ were female and $75 \%$ were originally from an urban residence. Of the students that were considered knowledgeable, $42 \%$ were full time. Table 2 presents students' computer and printer access. From the total of 1096 students, 53\% reported that they have access to a computer and 91\% to a printer. From those who have access to a computer, 
Table 1 Demographic characteristics of the study population $(\mathrm{N}=1096)$

\begin{tabular}{|c|c|c|c|}
\hline Variable & Category & $\mathbf{N}$ & Percent (\%) \\
\hline \multirow[t]{4}{*}{ Age } & $15-19$ & 235 & 21.4 \\
\hline & $20-24$ & 818 & 74.6 \\
\hline & $25-29$ & 36 & 3.3 \\
\hline & $30-34$ & 7 & 0.6 \\
\hline \multirow[t]{2}{*}{ Sex } & Male & 807 & 73.6 \\
\hline & Female & 289 & 26.4 \\
\hline \multirow[t]{2}{*}{ Previous residency } & Urban & 673 & 61.4 \\
\hline & Rural & 423 & 38.6 \\
\hline \multirow{6}{*}{$\begin{array}{l}\text { Father educational } \\
\text { status }\end{array}$} & Illiterate & 180 & 16.4 \\
\hline & Read and write only & 313 & 28.6 \\
\hline & Primary education & 157 & 14.6 \\
\hline & High school & 96 & 8.8 \\
\hline & Diploma & 350 & 31.9 \\
\hline & Degree and above & & \\
\hline \multirow{6}{*}{$\begin{array}{l}\text { Mother educational } \\
\text { status }\end{array}$} & Illiterate & 350 & 31.9 \\
\hline & Read and write only & 290 & 26.5 \\
\hline & Primary education & 119 & 10.9 \\
\hline & High school & 132 & 12.0 \\
\hline & Diploma & 205 & 18.7 \\
\hline & Degree and above & & \\
\hline \multirow[t]{11}{*}{ Department } & Medicine & 317 & 28.9 \\
\hline & Nurse & 130 & 19.3 \\
\hline & Health officer & 54 & 9.3 \\
\hline & Anesthesia & 212 & 3.4 \\
\hline & Physiotherapy & 101 & 1.8 \\
\hline & Midwifery & 37 & 7.8 \\
\hline & Psychiatry & 20 & 2.2 \\
\hline & Optometry & 87 & 3.6 \\
\hline & Laboratory & 24 & 6.8 \\
\hline & Pharmacy & 39 & 11.9 \\
\hline & Environmental and occupation & 75 & 4.9 \\
\hline \multirow[t]{2}{*}{ College attending } & Extension & 230 & 21.0 \\
\hline & Regular & 866 & 79.0 \\
\hline \multirow[t]{6}{*}{ Level of education } & First year & 358 & 32.7 \\
\hline & Second year & 365 & 33.3 \\
\hline & Third year & 198 & 18.1 \\
\hline & Fourth year & 122 & 11.1 \\
\hline & Fifth year & 33 & 3.0 \\
\hline & Six year & 20 & 1.8 \\
\hline \multirow[t]{3}{*}{ Religion } & Orthodox & 928 & 84.7 \\
\hline & Muslim & 88 & 8.0 \\
\hline & Protestant & 70 & 6 \\
\hline
\end{tabular}

$6 \%$ had a personal computer, $14 \%$ had access via an Internet cafe and $28 \%$ had access to computers at the university. Table 3 presents responses to questions on computer skills and training. From the overall respondents, $41 \%$ were familiar with computers through personal study (self learning) and experience, however $24 \%$ were familiar with computers through courses given at the university, and only $8 \%$ acquired computer knowledge through special computer training outside the University.

Among all respondents, 49\% self rated their basic general IT skills as competent in some basic IT skill, $8 \%$ as competent in most basic IT skills, $44 \%$ rated themselves as less competent or a beginner in general IT skills and half of the respondents described their IT training as poor.

Table 3 presents responses to questions on computer skills and training.

\section{Student ICT utilization}

Table 3 presents responses to questions on computer skills and training. Around a quarter (23\%) of the study population had been using computers for more than three years. One quarter of the respondents (29\%) reported irregular use of computers. Almost half of the subjects (49\%) were competent in some basic skills. About $10 \%$ of the students responded that, they use a computer on daily basis, whereas $33 \%$ use a computer once a week and nearly $41 \%$ the students use a computer once in a month or very few times in a year. About half of the students (47\%) have never used any form of electronic communication. From the total study participants only $8 \%$ used electronic communication like email and chat almost every day.

The results also showed that among the electronic communication means, email or chat services are the most widely used applications (51\%), followed by the Internet search engines to look up academic information $(49 \%)$ and $38 \%$ of students utilize the Internet to look up information about people, things and ideas.

The computer center at the College of Medicine and Health Sciences was visited almost every day by only forty three $(4 \%)$ of the respondents, about $24 \%$ used the computer centre once a month and $20 \%$ of the respondents visited the centre once a week. $8 \%$ of the students used the centre $2-3$ days per week, but $45 \%$ of the respondents never used the centre at all.

\section{Factors associated with the utilization of ICT}

Table 4 presents factors associated with the utilization of ICT. Binary logistic regression was used and those whose $\mathrm{p}$ values were less than or equal to 0.2 were fitted to multiple logistic regression. The regression analysis showed that those students who came from educated 
Table 2 Response to questionnaire items on computer and printer access amongst a sample of college of medicine and health science students university of Gondar $(N=1096)$

\begin{tabular}{|c|c|c|c|c|c|c|c|}
\hline \multirow[t]{2}{*}{ Question } & \multirow[t]{2}{*}{ Response } & \multicolumn{2}{|c|}{ Male } & \multicolumn{2}{|c|}{ Female } & \multicolumn{2}{|c|}{ Total } \\
\hline & & $\mathbf{N}$ & $\%$ & $\mathbf{N}$ & $\%$ & $\mathrm{~N}$ & $\%$ \\
\hline \multirow[t]{2}{*}{ Do you have access to a computer? } & Yes & 413 & 51 & 165 & 57 & 578 & 52.7 \\
\hline & No & 394 & 49 & 124 & 43 & 518 & 47.3 \\
\hline \multirow[t]{4}{*}{ Where do you have access to computers? } & At the University & 233 & 29 & 75 & 26 & 308 & 28.1 \\
\hline & At home & 35 & 4 & 35 & 12 & 70 & 6.4 \\
\hline & Other place (Internet cafe) & 111 & 14 & 39 & 13 & 150 & 13.7 \\
\hline & At both home and Internet café & 27 & 3 & 23 & 8 & 50 & 4.6 \\
\hline \multirow[t]{3}{*}{ How do you describe the access and availability of the computer? } & Good / very good & 84 & 10 & 37 & 13 & 121 & 11 \\
\hline & Adequate & 242 & 30 & 83 & 29 & 325 & 29.7 \\
\hline & Poor/ very poor & 481 & 60 & 169 & 58 & 650 & 59.3 \\
\hline \multirow[t]{2}{*}{ Do you have access to a printer } & Yes & 66 & 8 & 34 & 12 & 100 & 9.1 \\
\hline & No & 741 & 92 & 255 & 88 & 996 & 90.9 \\
\hline \multirow[t]{3}{*}{ How would you describe the access and availability of the printer } & Good / very good & 133 & 16 & 44 & 15 & 177 & 16.1 \\
\hline & Adequate & 183 & 23 & 78 & 27 & 261 & 23.8 \\
\hline & Poor/ very poor & 491 & 61 & 167 & 58 & 658 & 60 \\
\hline
\end{tabular}

families were almost four times more likely to utilize ICT compared to non educated family [AOR $=4.36,95 \%$ CI: 2.16-8.80]. Those students competent in most general IT skill were almost twice as likely to utilize ICT compared with less competent or beginner general IT skill students, $[\mathrm{AOR}=1.63,95 \% \mathrm{CI}$ : 1.13-2.34]. Students competent in word processing were six times more likely to utilize ICT compared to those without this skill [AOR $=5.83,95 \%$ CI: 3.15- 10.79].

Students who had ICT knowledge were twice more likely to utilize ICT compared to without this knowledge $[\mathrm{AOR}=2.47,95 \%$ CI:1.72-3.55], and students with perceived good quality of IT education were two times more likely to utilize ICT compared to those who perceived their education to be of poor quality [AOR $=1.96,95 \%$ CI: 1.36-2.84].

\section{Discussion}

The present study examined the knowledge and utilization of ICT and its associated factors in CMHS, University of Gondar. The result of this study revealed that half of students had ICT knowledge, which is similar to the study conducted in Medical school of Ahmadu Bello University, Zaria, Nigeria [6] and a bit lower than a study conducted in India (58\%) [7]. Despite the introduction of IT into the curriculum of preparatory schools and in the universities, the level of computer literacy among CMHS students is very low. This perhaps may due to poor access to computer among the students or the inadequacy of the IT courses provided in the university [8].
The study also showed utilization dissimilarities among students in urban and rural areas. This is similar to a study in Ghana where students in urban areas have more positive attitudes towards ICT use compared to students in rural areas [9]. The difference in utilization may be explained by the availability of ICT facilities (such as Internet connectivity, electricity, telephone etc.) in the urban areas as compared to the rural areas in most developing countries. In addition, people are more likely to respond positively to something or someone after increased exposure for example to ICT tools in this case.

Among CMHS students half of the respondents (49.5\%) describe their IT training as poor and only 18\% describe it as good, which is quite different from the study conducted on students ICT knowledge familiarity in a dental institution in India, where nearly half the subjects $(48 \%)$ reported that the quality of IT training received was adequate [10].

Hence, we recommend the college to review the ICT training run in the college and make necessary adjustments based on these findings. The majority of the students do not have their own computers, and only $47 \%$ of the students have access to computers in college. This figure is low and comparable to study carried out in Nigeria [6]. This might be due to financial constraints preventing the students from owning a computer. In addition, the low utilization of computers might be the inadequacy of computer labs and computers in the college where there are only two computer laboratory each with about 50 computers for all the students in the college. If students 
Table 3 Responses to questionnaire items on computer skills and training among CMHS students $(\mathrm{N}=1096)$

\begin{tabular}{|c|c|c|c|c|}
\hline \multirow[t]{2}{*}{ Variable } & & \multicolumn{2}{|c|}{ Utilization } & \multirow[t]{2}{*}{ COR $(95 \% \mathrm{Cl})$} \\
\hline & & Yes & No & \\
\hline \multirow[t]{2}{*}{ Previous residency } & Urban & 371 & 302 & $2.70(2.09-3.49)^{*}$ \\
\hline & Rural & 132 & 291 & 1 \\
\hline \multirow[t]{5}{*}{ Mother educational status } & Illiterate & 76 & 99 & 1 \\
\hline & Read and write & 96 & 254 & $1.23(.83-1.82)$ \\
\hline & Primary school & 125 & 165 & $1.41(1.00-1.99)^{*}$ \\
\hline & High school & 71 & 48 & $1.82(1.17-2.85)^{*}$ \\
\hline & Higher education & 86 & 46 & $2.44(1.47-4.07)^{*}$ \\
\hline \multirow[t]{5}{*}{ Father educational status } & Illiterate & 125 & 80 & 1 \\
\hline & Read and write & 57 & 123 & $2.00(1.44-2.78)^{*}$ \\
\hline & Primary school & 114 & 199 & $3.19(2.18-4.67)^{*}$ \\
\hline & High school & 72 & 85 & $3.91(2.53-6.04)^{*}$ \\
\hline & Higher education & 51 & 45 & $4.94(3.22-7.59)^{*}$ \\
\hline \multirow[t]{2}{*}{ Computer access in the university } & Yes & 236 & 232 & $1.38(1.07-1.76)^{*}$ \\
\hline & No & 267 & 361 & 1 \\
\hline \multirow[t]{2}{*}{ Computer access at home } & Yes & 141 & 55 & $3.81(2.71-5.34)^{*}$ \\
\hline & No & 362 & 538 & 1 \\
\hline \multirow[t]{3}{*}{ Self rated IT skill } & Good / very good & 355 & 122 & $7.10(4.26-11.81)^{*}$ \\
\hline & Adequate & 213 & 320 & $4.37(3.34-5.72)^{*}$ \\
\hline & Poor/ very poor & 25 & 61 & 1 \\
\hline \multirow[t]{3}{*}{ Ability to use word processor } & Competent in most skill & 38 & 32 & $8.85(5.36-4.60)^{*}$ \\
\hline & Competent in basic skill & 41 & 47 & $7.44(5.61-9.86)^{*}$ \\
\hline & Unable beginner & 416 & 513 & 1 \\
\hline \multirow[t]{6}{*}{ ICT familiarization } & Through a course in the university & 96 & 254 & 1 \\
\hline & Personal study and experience & 125 & 165 & $2.20(1.59-3.04)^{*}$ \\
\hline & Special course & 71 & 48 & $2.22(1.36-3.63)^{*}$ \\
\hline & Course in the university, personal study, ,experience and special study & 86 & 46 & $4.14(2.61-6.56)^{*}$ \\
\hline & Special course, personal study, and experience & 125 & 80 & $2.12(1.30-3.47)^{*}$ \\
\hline & Course in the university and experience & & & $2.94(1.77-4.86)^{*}$ \\
\hline \multirow{2}{*}{$\begin{array}{l}\text { Access to computer in the café and other } \\
\text { non specific place }\end{array}$} & Yes & 316 & 262 & $2.13(1.67-2.72)^{*}$ \\
\hline & No & 182 & 331 & 1 \\
\hline \multirow[t]{2}{*}{ Knowledge } & Knowledgeable & 164 & 284 & 1 \\
\hline & Not knowledgeable & 171 & 567 & $6.34(4.86-8.26)^{*}$ \\
\hline \multirow{3}{*}{$\begin{array}{l}\text { Quality of teaching in computer in } \\
\text { the university }\end{array}$} & Good / very good & 355 & 122 & $4.02(2.85-5.67)^{*}$ \\
\hline & Adequate & 213 & 320 & $3.90(2.94-5.17)^{*}$ \\
\hline & Poor/ very poor & 25 & 61 & 1 \\
\hline \multirow{3}{*}{$\begin{array}{l}\text { How do you describe the access computer } \\
\text { and printer }\end{array}$} & Good / very good & 38 & 32 & $2.70(1.80-4.04)^{*}$ \\
\hline & Adequate & 41 & 47 & $1.51(1.16-1.98)^{*}$ \\
\hline & Poor/ very poor & 416 & 513 & 1 \\
\hline
\end{tabular}

do not have access to ICT then many of the perceived advantages of using ICT for education will not translate into reality.

This study also has shown that only $46 \%$ of respondents could use a computer, which is similar to the study conducted in a Nigerian teaching hospital which showed that among first year clinical and nursing students only 43\% [11] could use computers. However it is lower when compared to studies carried out among medical students in Malaysia which showed $61 \%$ could use a computer [12]. As discussed earlier, access to computers, previous residency, knowledge about ICT and maternal education contribute to such low levels of utilization [13]. 
Table 4 Factor associated with the utilization of ICT among CMHS students $(N=1096)$

\begin{tabular}{|c|c|c|c|c|c|}
\hline \multirow[t]{2}{*}{ Variable } & & \multicolumn{2}{|c|}{ Utilization } & \multirow[t]{2}{*}{ COR $(95 \% \mathrm{Cl})$} & \multirow[t]{2}{*}{ AOR $(95 \% \mathrm{Cl})$} \\
\hline & & Yes & No & & \\
\hline \multirow[t]{2}{*}{ Previous residency } & Urban & 371 & 302 & $2.70(2.09-3.49)^{*}$ & $1.03(.687-1.55)$ \\
\hline & Rural & 132 & 291 & 1 & 1 \\
\hline \multirow[t]{5}{*}{ Maternal educational status } & Illiterate & 76 & 99 & 1 & 1 \\
\hline & Read and write & 96 & 254 & $1.23(.83-1.82)$ & $1.59(1.01-2.52)^{*}$ \\
\hline & Primary school & 125 & 165 & $1.41(1.00-1.99)^{*}$ & $2.31(1.19-4.48)^{*}$ \\
\hline & High school & 71 & 48 & $1.82(1.17-2.85)^{*}$ & $4.36(2.16-8.80)^{*}$ \\
\hline & Higher education & 86 & 46 & $2.44(1.47-4.07)^{*}$ & $2.05(1.02-4.13)^{*}$ \\
\hline \multirow[t]{3}{*}{ Self rated IT skill } & Good / very good & 355 & 122 & $7.10(4.26-11.81)^{*}$ & $1.63(1.13-2.34)^{*}$ \\
\hline & Adequate & 213 & 320 & $4.37(3.34-5.72)^{*}$ & $1.20(.60-2.40)$ \\
\hline & Poor/ very poor & 25 & 61 & 1 & 1 \\
\hline \multirow[t]{3}{*}{ Ability to use word processor } & Competent in most skill & 38 & 32 & $8.85(5.36-4.60)^{*}$ & $4.73(3.37-6.64)^{*}$ \\
\hline & Competent in basic skill & 41 & 47 & $7.44(5.61-9.86)^{*}$ & $5.83(3.1510 .79)^{*}$ \\
\hline & Unable beginner & 416 & 513 & 1 & 1 \\
\hline \multirow[t]{2}{*}{ Knowledge } & Knowledgeable & 164 & 284 & 1 & 1 \\
\hline & Not knowledgeable & 171 & 567 & $6.34(4.86-8.26)^{*}$ & $2.47(1.72-3.55)^{*}$ \\
\hline \multirow[t]{3}{*}{ Perceived quality of teaching in computer in the university } & Good / very good & 355 & 122 & $4.02(2.85-5.67)^{*}$ & $2.49(1.60-3.86)^{*}$ \\
\hline & Adequate & 213 & 320 & $3.90(2.94-5.17)^{*}$ & $1.96(1.36-2.84)^{*}$ \\
\hline & Poor/ very poor & 25 & 61 & 1 & 1 \\
\hline
\end{tabular}

The findings in this study have shown, only half of the students ever used electronic communication (e.g. E-mail or "chat rooms"). This finding corresponds to the study carried out in Coastal South India (51\%) [14] but is lower than the studies conducted in Nigeria (76.4\%) [11] and Hadramout University, Yemen (76.2\%) [15]. The reason for this perhaps is the limited access to computers and cost of Internet services. The results of this study also revealed that half of the students used Internet to look up academic information, which is lower than the study conducted in Lahore, Pakistan 61.0\% [16]. There may be a number of reasons for this difference in use of Internet. Problems such as lack of access to Internet, limited training in how to use the Internet, or absence of tasks set by the instructors that require use of online databases such as UpToDate may have all contributed.

Hence, emphasis should be placed on accommodating training in ICT as well as ICT-enabled teaching and learning. ICT should be taught as a subject, and integrated as a pedagogical tool for teaching and learning in other subject areas.

\section{Conclusion}

Students in the College of Medicine and Health Sciences, University of Gondar had inadequate knowledge of ICT and very low ICT utilization. Establishing an undergraduate students' computer lab, incorporating information-based discipline, and strengthening health informatics training would equip them with the skills they need to utilize ICT. CMHS leaders should be aware of this existing gap, and start to bring fundamental changes in their institutions with regard to ICT. Further research should focus on designing and evaluating computer and IT training for students.

Though, this study is the first of its kind in our college and probably in the nation, it has its own limitations. Firstly the study depends on self-reported data, which might be susceptible to recall bias. Secondly the questions we prepared to assess knowledge and utilization may not be comprehensive enough to assess all the issues correctly.

\section{Abbreviations}

AOR: Adjusted Odd Ratio; CMHS: College of medicine and health sciences; Cl: Confidence Interval; ICT: Information communication technology;

IT: Information technology.

\section{Competing interests}

The authors declare that they have no competing interests.

\section{Authors' contributions}

SAW conceived, designed and coordinated the study, participated in data acquisition, carried out data collection, analysis and interpretation, drafted the manuscript. YKG and DTZ participated in designing the study, review of the manuscript, and analysis. All the authors have read and approved the final manuscript.

Acknowledgements

We thank the students for participating in the study. 


\section{Author details}

'Institute of Public Health, Department of Health Informatics, University of Gondar, Gondar, Ethiopia. ${ }^{2}$ Institute of Public Health, Department of Epidemiology and Biostatistics, University of Gondar, Gondar, Ethiopia.

Received: 3 August 2012 Accepted: 27 February 2013

Published: 3 March 2013

\section{References}

1. Mikre F: The Roles of Information Communication Technologies in

Education: Review Article with Emphasis to the Computer and Internet. Ethiopian Journal of Education and Sciences 2012, 6:109-126.

2. Kamssu AJ, Siekpe JS, Ellzy JA: Shortcomings to Globalization: Using Internet Technology and Electronic Commerce in Developing Countries. J Dev Areas 2004, 38:151-169.

3. Venkatesh V, Bala H, Sykes TA: Impacts of Information and Communication Technology Implementations on Employees' Jobs in Service Organizations in India: A Multi-Method Longitudinal Field Study. Prod Oper Manag 2010, 19:591-613.

4. Zucker AA, Light D: Laptop Programs for Students. Science 2009, 323:82-85.

5. Bank W: Survey of ICT and Education in Africa: Ethiopia Country Report. 2007.

6. Ameh N, Kene T, Ameh E: Computer knowledge amongst clinical year medicalstudents in a resource poor setting. Afr Health Sci 2008, 8:40-43.

7. Gour N, srivastava D: Knowledge of computer among healthcare professionals of India: a key toward e-health. Telemed J E Health 2010, 16:957-962.

8. Olatoye R: Gender Factor in Computer Anxiety, Knowledge and Utilization among Senior Secondary School Students in Ogun State, Nigeria. African Journals OnLine 2009, 7:2430-2444.

9. Sarfo F, Amartei A, Adentwi K, Brefo C: Technology and gender equity: Rural and urban students' attitudes towards information and communication technology. Journal of Media and Communication Studies 2011, 3:221-230

10. Kumar S, Balasubramanyam G, Duraiswamy P, Kulkarni S: Information Technology Practices Amongst Dental Undergraduate Students at a Private Dental Institution in India. Journal of Dentistry, Tehran University of Medical Sciences, Tehran, Iran 2009, 6:130-138.

11. Ajuwon G: Computer and Internet use by first year clinical and nursing students in a Nigerian teaching hospital. BMC Med Inform Decis Mak 2003, 3:10.

12. Nurjahan $\mathrm{M}, \mathrm{Lim} \mathrm{T}$, Yeong S, Foong A, Ware J: Utilization of information technology in medical education: a questionnaire survey of students in a Malaysian institution. Med. J. Malaysia 2002, 57(Suppl E):58-66.

13. Howard PN: Testing the Leap-Frog hypothesis. The impact of existing infrastructure and telecommunications policy on the global digital divide. In Information, Communication \& Society 2007, 10:133-157.

14. Unnikrishnan B, Kulshrestha V, Saraf A, Agrahari A, Prakash S, Samantaray L, Parida A: Pattern of computer and Internet use among medical students in Coastal South India. South East Asian Journal of Medical Education 2008, 2:18-28.

15. Bin G, Abdulla S: Using computer and internet for medical literature searching among medical students in Hadramout University, Yemen. Online Journal Of Health And Allied Science 2008, 7:1-4.

16. Jadoon N, Zahid M, Mansoorulhaq H, Ullah S, Jadoon B, Raza A, Hussain M, Yaqoob R, Shahzad M: Evaluation of Internet access and utilization by medical students in Lahore, Pakistan. BMC Med Inform Decis Mak 2011 $11: 37$

doi:10.1186/1472-6947-13-31

Cite this article as: Woreta et al:: Knowledge and utilization of information communication technology (ICT) among health science students at the University of Gondar, North Western Ethiopia. BMC Medical Informatics and Decision Making 2013 13:31.

\section{Submit your next manuscript to BioMed Central and take full advantage of:}

- Convenient online submission

- Thorough peer review

- No space constraints or color figure charges

- Immediate publication on acceptance

- Inclusion in PubMed, CAS, Scopus and Google Scholar

- Research which is freely available for redistribution 